\title{
Efficiency of using indexes method in the comprehensive assessment of the genetic collection in the winter hexaploid triticale
}

\author{
Lyubov Bekish ${ }^{1, *}$, Valentina Uspenskaya ${ }^{1}$, Denis Chashin $^{1}$, and Nadezhda Chikida $^{2}$ \\ ${ }^{1}$ Leningrad Research Agriculture Institute Branch of Russian Potato Research Centre; Institutskaya \\ st., 1, Belogorka village, Gatchinsky district, 188338 Leningrad region, Russia \\ ${ }^{2}$ N.I. Vavilov All-Russian Institute of Plant Genetic Resources; B. Morskaya st., 42, 44, 190000 St. \\ Petersburg, Russia
}

\begin{abstract}
The paper presents the comparative assessment results of 53 collection samples of winter hexaploid triticale of various ecological and geographical origin using traditional statistical methods and methods of complex indices $(J k)$, perspectivity indices $(J p)$, ecological plasticity $(J s p)$, Finno-Scandinavian (FSJ), Mexican (Mi), and adaptive potential. By the traditional statistical method, high-yield varieties with high values of individual elements of plant productivity were identified: (k-3717) Kaskad, (k-4071) Ramzay, (k-3969) Trizub, (k-3924) Popsuevskaya, (k-3900) Prometey, (k-4095) Shalanda, (k-4097) Buket. The following varieties were identified by the method of complex indices: (k-3909) Topaz, (k3717) Kaskad, (k-3931) Skif, (k-4071) Ramzay, (k-3969) Trizub, (k-4074) Valentin-90, (k-4078) Bordo, (k-3924), Popsuevskaya, (k-3968) Interes, (k-3901) Mars, (k-3900) Prometey, (k-4003) Disko, (k-3999) Anvo, (k3701) Fidelio, (k-4095) Shalanda, (k-4097) Buket. According to the indices' complex that determine the prospects of the variety, the grainforming ability of its ear, resistance to lodging, high adaptive potential, the following varieties were identified: (k-3909) Topaz, (k-3717) Kaskad, (k4020) Zavet, (k-3932) Skolot, (k-4071) Ramzay, (k-4074) Valentin-90, (k4076) Knyaz, (k-3924), Popsuevskaya, (k-3968) Interes, (k-3966) Ajax, (3965) Pshenichne, (k-3900) Prometey, (k-4003) Disko, (k-4005) Korvetta, (k-3999) Anvo, (k-3701) Fidelio, (k-4095) Shalanda, (k-4097) Buket, (k3562) Antey, (k-3582) Patriot. The study results allow to speak about the usage efficiency of the indices method for a comprehensive winter triticale assessment.
\end{abstract}

\section{Introduction}

Triticale is a promising new crop for the feed and baking industries [1,2]. This crop's sown area in Russia and abroad is constantly expanding - this is the merit of selectioners who are constantly working on the creation of new varieties.

\footnotetext{
* Corresponding author: melinda_08@mail.ru
} 
The State Register of Selection Inventions as of 2021 includes 96 varieties of winter and 20 varieties of spring triticale [3].

Currently, breeding work with triticale is being intensively carried out in the Don, Krasnodar, Voronezh, Moscow, Stavropol Research Institutes of Agriculture, as well as in neighboring countries (Ukraine, Belarus, Kazakhstan) [4]. In the Leningrad Research Agriculture Institute Branch of Russian Potato Research Centre, breeding work with this crop began in 2002 with the study of variety samples from the collection of the N.I. Vavilov AllRussian Institute of Plant Genetic Resources with the subsequent work expansion on the full scheme of the breeding process.

New varieties of winter triticale are distinguished by increased winter resistance, drought resistance, resistance to the most dangerous diseases, high yield potential, increased content of complete protein, which determines the high fodder value and nutritional value of this crop. So in 2020, Bilinda winter triticale variety was included in the State Register of Selection Inventions, which was approved to be used in the North-West (2) region of Russia. This mid-season, winter-resistant, high-yielding variety has a high adaptive potential to biotic and abiotic stressors when grown for green forage [5].

However, a significant expansion of triticale sowing poses new tasks for breeders to create and introduce varieties of winter triticale with wide ecological adaptation [6,7].

The development of winter triticale breeding in the North-West region of Russia requires a comprehensive study of the replenishing gene pool from the world collection of N.I. Vavilov All-Russian Institute of Plant Genetic Resources in order to identify sources of economically valuable traits and create new genotypes [8].

Grain yield is an integral indicator of plant productivity characterizing the ability of a variety to realize its genetic potential in specific soil and climatic conditions. This is the interaction result of the quantitative traits of a plant with environmental conditions. Both traditional statistical methods and indices methods are used for a comprehensive assessment of high-yielding samples.

The scientific literature describes the methods of complex indices (Ik), perspectivity indices (Ip), ecological plasticity (Isp), Finno-Scandinavian (FSi), Mexican (Mi) and adaptation potential, which allow efficient selection for a comprehensive assessment of high-yielding samples $[9,10,11]$.

The purpose of our research was to determine the efficiency of using the indices method in a comprehensive assessment of winter hexaploid triticale collection samples by the main elements of the yield structure under the conditions of the Leningrad region.

\section{Materials and methods}

Winter hexaploid triticale varieties of various ecological and geographical origin from the collection of the N.I. Vavilov All-Russian Institute of Plant Genetic Resources (VIR) were used as research materials.

Experiments' establishment, phenological observations, field and laboratory assessments were carried out according to generally accepted methods (12-15).

Sowing of the collection nursery was carried out on plots of $1 \mathrm{~m}^{2}$, threefold replication, sown variety - standard Kornet variety.

\section{Research results}

The set of collection samples was diverse and represented by promising zoned varieties, as well as sources and donors of various traits and properties: high productivity, early maturity, lodging resistance. 
In the collection nursery, 53 samples of winter triticale from different countries of the world were studied: Russia, Ukraine, Belarus, Poland, Romania (table 1).

Table 1. The origin of triticale variety samples.

\begin{tabular}{|c|c|}
\hline Sample name & Origin \\
\hline Nemchinovsky -56, Antey & Russia, Moscow region \\
\hline $\begin{array}{c}\text { Kornet, Konsul, Almaz, Topaz, Bard, Don, } \\
\text { Kaskad, Zavet, Skif, Skolot, Ramzay, Trizub, } \\
\text { Tornado }\end{array}$ & Russia, Rostov region \\
\hline $\begin{array}{c}\text { Proryv, Barun, Mudrets, Makar, Dozor, Valentin- } \\
\text { 90, Knyaz, Bordo, Patriot }\end{array}$ & Russia, Krasnodar Krai \\
\hline Sirs - 57 & Russia, Novosibirsk region \\
\hline Beta & Russia, Tatarstan \\
\hline $\begin{array}{c}\text { Popsuevskaya, Gorchinske, Interes, Ayaks, } \\
\text { Pshenichne, Svityaz, Chernobrivets, Shalanda, } \\
\text { Buket, Markiyan }\end{array}$ & Ukraine \\
\hline Amulet, Utro, Mars, Prometey, Impuls & Belarus \\
\hline $\begin{array}{c}\text { Argento, Aswo, Disko, Floiras, Corvetta, Prado, } \\
\text { Anvo, Fidelio, Eldorado, Witon, Monica }\end{array}$ & Poland \\
\hline Colina & Romania \\
\hline
\end{tabular}

For all variety samples of winter triticale, the elements of the yield structure were assessed. Their agrobiological characteristics are presented in Table 2.

Over the years of research, variety samples of winter triticale that reliably surpass the standard Kornet $(5.53 \mathrm{t} / \mathrm{ha})$ in yield were identified - Shalanda (8.24 t/ha) and Buket (8.02 t/ha). Kaskad (6.39 t/ha), Ramzay (6.71 t/ha), Knyaz (5.78 t/ha), Trizub (5.93 t/ha), Popsuevskaya (6.47 t/ha), Interes (6.03 t/ha), Prometey (6.62 t/ha), Anvo (6.24 t / ha), Chernobrivets (6.33 t/ha), Sirs - 57 (6.20 t/ha). Dozor (2.0 t/ha) and Argento (2.25 t/ha) variety samples had a low yield over the years of research.

According to the "stem length" indicator, all variety samples were divided into three groups: tall (over $115 \mathrm{~cm}$ ), medium-sized (from 90 to $115 \mathrm{~cm}$ ) and short-stemmed (less than $90 \mathrm{~cm})$. The tallest variety samples - Monica $(115 \mathrm{~cm})$, Popsuevskaya $(118 \mathrm{~cm})$ and Tornado $(133 \mathrm{~cm})$ exceeded the standard variety Kornet $(108 \mathrm{~cm})$ in stem length by $6-26$ $\mathrm{cm}$. The shortest-stemmed samples $(72-88 \mathrm{~cm})$ were Ramzay $(72 \mathrm{~cm})$, Zavet, Proryv $(75$ $\mathrm{cm})$, Korvetta, Skif, Skolot $(77 \mathrm{~cm})$, Pshenichne, Makar $(78 \mathrm{~cm})$, Bordo $(85 \mathrm{~cm})$, Dozor, Ajax, Floiras $(87 \mathrm{~cm})$, Fidelio, Don $(88 \mathrm{~cm})$; those were identified as sources of short stature.

In terms of the "ear length" indicator, all studied samples had values in the range from 8 to $11.4 \mathrm{~cm}$. The highest values for the ear length $(11.3-11.5 \mathrm{~cm})$ were shown by Popsuevskaya, Skif, Dozor, Gorchinske variety samples, the least value of the ear length $(8.0 \mathrm{~cm})$ were observed in Monica and Eldorado samples.

Table 2. Agrobiological characteristics of winter triticale variety samples (average data for 2018 - 2020).

\begin{tabular}{|c|c|c|c|c|c|c|c|}
\hline \multirow{2}{*}{ It.No. } & \multirow{2}{*}{ Sample } & \multirow{2}{*}{$\underset{\text { t/ha }}{\text { Crop yield, }}$} & \multicolumn{2}{|c|}{ Length, $\mathrm{cm}$} & \multirow{2}{*}{$\begin{array}{l}\text { The number } \\
\text { of grains per } \\
\text { ear, pcs. }\end{array}$} & \multirow{2}{*}{$\begin{array}{c}\text { Mass of } \\
\text { grain from } \\
\text { an ear, } \\
\text { g }\end{array}$} & \multirow{2}{*}{$\begin{array}{l}\text { Mass of } \\
1000 \\
\text { grains, } \\
\mathrm{g}\end{array}$} \\
\hline & & & stem & ear & & & \\
\hline 1 & Kornet -St. & 5.53 & 108.0 & 9.0 & 65.5 & 4.13 & 54.9 \\
\hline 2 & Nemchinovsky -56 & 5.08 & 97.0 & 10.0 & 60.5 & 3.43 & 55.7 \\
\hline
\end{tabular}




\begin{tabular}{|c|c|c|c|c|c|c|c|}
\hline 3 & Konsul & 4.25 & 98.0 & 10.2 & 69.0 & 4.05 & 53.2 \\
\hline 4 & Almaz & 4.90 & 93.0 & 9.4 & 60.1 & 3.28 & 48.8 \\
\hline 5 & Topaz & 4.79 & 98.0 & 10.0 & 65.3 & 4.08 & 57.0 \\
\hline 6 & Bard & 3.08 & 98.0 & 9.4 & 64.0 & 3.28 & 47.7 \\
\hline 7 & Don & 4.97 & 88.0 & 9.0 & 58.9 & 2.98 & 52.5 \\
\hline 8 & Kaskad & 6.39 & 103.0 & 10.3 & 72.8 & 3.80 & 46.1 \\
\hline 9 & Zavet & 3.82 & 75.0 & 10.4 & 64.7 & 3.63 & 51.3 \\
\hline 10 & Skif & 5.05 & 77.0 & 11.4 & 81.7 & 4.08 & 44.0 \\
\hline 11 & Skolot & 3.88 & 78.0 & 10.8 & 68.2 & 3.98 & 56.7 \\
\hline 12 & Ramzay & 6.71 & 72.0 & 10.9 & 68.0 & 4.05 & 56.15 \\
\hline 13 & Proryv & 4.28 & 75.0 & 9.1 & 54.2 & 2.70 & 49.0 \\
\hline 14 & Barun & 3.27 & 103.0 & 10.7 & 53.3 & 2.87 & 53.3 \\
\hline 15 & Mudrets & 5.27 & 93.0 & 11.1 & 57.1 & 3.53 & 56.7 \\
\hline 16 & Makar & 3.80 & 78.0 & 9.2 & 53.5 & 3.63 & 62.1 \\
\hline 17 & Dozor & 2.00 & 87.0 & 11.4 & 51.2 & 3.13 & 55.0 \\
\hline 18 & Valentin-90 & 5.17 & 92.0 & 9.9 & 75.8 & 4.25 & 52.7 \\
\hline 19 & Knyaz & 5.78 & 75.0 & 10.5 & 60.5 & 3.70 & 59.0 \\
\hline 20 & Bordo & 5.44 & 85.0 & 10.4 & 66.7 & 4.10 & 57.0 \\
\hline 21 & Trizub & 5.93 & 108.0 & 9.8 & 54.3 & 3.23 & 56.1 \\
\hline 22 & Beta & 4.62 & 97.0 & 9.0 & 68.9 & 3.48 & 49.5 \\
\hline 23 & Popsuevskaya & 6.47 & 118.0 & 11.3 & 57.9 & 3.83 & 64.4 \\
\hline 24 & Gorchinske & 2.89 & 95.0 & 11.5 & 63.8 & 3.53 & 45.8 \\
\hline 25 & Interes & 6.03 & 100.0 & 10.0 & 72.3 & 3.93 & 49.0 \\
\hline 26 & Ayaks & 3.60 & 87.0 & 10.6 & 68.8 & 4.05 & 49.6 \\
\hline 27 & Pshenichne & 4.10 & 78.0 & 11.0 & 68.9 & 3.87 & 54.0 \\
\hline 28 & Svityaz & 4.98 & 105.0 & 10.6 & 55.3 & 3.59 & 56.4 \\
\hline 29 & Amulet & 4.20 & 98.0 & 9.4 & 67.3 & 3.15 & 47.0 \\
\hline 30 & Utro & 4.50 & 95.0 & 10.4 & 62.8 & 2.73 & 41.0 \\
\hline 31 & Mars & 4.20 & 107.0 & 10.3 & 75.7 & 4.58 & 50.0 \\
\hline 32 & Prometey & 6.62 & 107.0 & 8.3 & 73.5 & 4.13 & 52.0 \\
\hline 33 & Impuls & 4.40 & 98.0 & 10.2 & 61.0 & 3.20 & 45.1 \\
\hline 34 & Argento & 2.25 & 105.0 & 9.7 & 64.9 & 3.73 & 52.8 \\
\hline 35 & Aswo & 3.53 & 95.0 & 9.6 & 52.4 & 2.63 & 48.0 \\
\hline 36 & Disko & 4.40 & 97.0 & 10.7 & 72.0 & 4.10 & 51.0 \\
\hline 37 & Floiras & 3.95 & 87.0 & 8.3 & 56.4 & 3.03 & 50.5 \\
\hline 38 & Korvetta & 4.97 & 77.0 & 10.3 & 65.2 & 3.38 & 50.5 \\
\hline 39 & Prado & 3.81 & 98.0 & 9.4 & 64.3 & 3.33 & 47.5 \\
\hline 40 & Anvo & 6.24 & 108.0 & 10.0 & 72.3 & 3.88 & 54.5 \\
\hline 41 & Fidelio & 5.23 & 88.0 & 10.8 & 73.7 & 4.43 & 53.0 \\
\hline 42 & Chernobrivets & 6.33 & 105.0 & 9.5 & 46.2 & 3.33 & 60.4 \\
\hline 43 & Shalanda & 8.24 & 115.0 & 11.0 & 73.2 & 4.90 & 62.0 \\
\hline 44 & Buket & 8.02 & 110.0 & 10.0 & 56.7 & 3.34 & 62.0 \\
\hline 45 & Markiyan & 4.64 & 105.0 & 9.5 & 56.1 & 3.69 & 48.0 \\
\hline 46 & Sirs-57 & 6.20 & 105.0 & 10.0 & 63.0 & 3.17 & 50.0 \\
\hline 47 & Eldorado & 3.32 & 98.0 & 8.0 & 53.4 & 2.52 & 49.8 \\
\hline 48 & Witon & 4.12 & 100.0 & 10.0 & 62.5 & 3.60 & 52.0 \\
\hline 49 & Colina & 4.81 & 98.0 & 9.5 & 66.9 & 3.80 & 54.4 \\
\hline
\end{tabular}




\begin{tabular}{|l|l|c|c|c|c|c|c|}
\hline 50 & Monica & 4.20 & 115.0 & 8.0 & 60.7 & 2.43 & 44.0 \\
\hline 51 & Antey & 4.26 & 105.0 & 10.0 & 65.9 & 3.77 & 61.7 \\
\hline 52 & Patriot & 3.27 & 78.0 & 11.0 & 59.6 & 3.50 & 50.4 \\
\hline 53 & Tornado & 4.66 & 133.0 & 9.0 & 60.0 & 2.77 & 55.6 \\
\hline & LSD 05 & 2.37 & 8.51 & 1.25 & 4.41 & 0.44 & 4.81 \\
\hline
\end{tabular}

In our studies, variety samples Kaskad, Skif, Valentin-90, Interes, Mars, Prometey, Disko, Anvo, Shalanda significantly differed according to the trait "number of grains per ear" from Kornet standard (65.6 pcs.), exceeding the standard in terms of the number of grains per year by $9.9-24.7 \%$. The highest number of grains was formed in the ear of the short-stemmed Skif variety sample $(81.7$ pcs.), the lowest - in Chernobrivets (46.2) (Table 2).

According to the "grain weight per ear" trait, the studied variety samples showed the value in the range from 2.43 to $4.9 \mathrm{~g}$, while the value of this indicator for Kornet standard was $4.13 \mathrm{~g}$. The highest values for the grain weight per ear $(4.3-4.9 \mathrm{~g})$ were observed in the variety samples Valentin-90, Mars, Fidelio, Shalanda, the lowest values (2.43-2.63 g) were shown by Polish variety samples Monica, Eldorado, Aswo.

According to "mass of 1000 grains" trait, the studied variety samples had values in the range from 41.0 to $64.4 \mathrm{~g}$, while the value of this indicator for Kornet standard was $54.9 \mathrm{~g}$. Larger grain (60.4-64.4 g) was formed in the variety samples Chernobrivets, Antey, Shalanda, Buket, Makar, Popsuevskaya. Utro, Skif and Monica varieties had the smallest grain (41.0-44.0 g).

Samples were identified for a complex of traits with high yield and high values of individual elements of its structure - Kaskad, Ramzay, Knyaz, Popsuevskaya, Interes, Prometey, Anvo, Chernobrivets, Shalanda, Buket.

All the studied variety samples of the winter hexaploid triticale collection were evaluated by the method of complex indices [10], the values of which are presented in Table 3. According to our research, variety samples Kaskad, Valentin-90, Popsuevskaya, Interes, Prometey, Anvo, Fidelio, Shalanda and Buket had high values of the complex index (1.44-3.21) and are of certain interest as an initial breeding material. When analyzing the complex assessment data of the winter triticale collection variety samples by the statistical method and the method of complex indices, five matches were found. Similar conclusions are available in studies on the triticale crop by other researchers [10].

Table 3. Comprehensive index assessment of winter triticale grain yield and elements of its structure.

\begin{tabular}{|c|l|c|c|c|c|c|}
\hline $\begin{array}{c}\text { It. } \\
\text { no. }\end{array}$ & Sample & $\begin{array}{c}\text { Crop } \\
\text { yield }\end{array}$ & $\begin{array}{c}\text { The number of } \\
\text { grains per ear }\end{array}$ & $\begin{array}{c}\text { Mass of } \\
\text { grain from an ear }\end{array}$ & $\begin{array}{c}\text { Mass of } \\
1000 \\
\text { grains }\end{array}$ & $\begin{array}{c}\text { Indices } \\
\text { multi } \\
\text { plication }\end{array}$ \\
\hline 1 & Kornet - St. & 1.16 & 1.03 & 1.16 & 1.04 & 1.44 \\
\hline 2 & Nemchinovsky -56 & 1.06 & 0.95 & 0.96 & 1.06 & 1.02 \\
\hline 3 & Konsul & 0.89 & 1.09 & 1.13 & 1.01 & 1.10 \\
\hline 4 & Almaz & 1.03 & 0.95 & 0.92 & 0.93 & 0.83 \\
\hline 5 & Topaz & 1.00 & 1.03 & 1.14 & 1.08 & 1.27 \\
\hline 6 & Bard & 0.65 & 1.00 & 0.92 & 0.9 & 0.54 \\
\hline 7 & Don & 1.04 & 0.93 & 0.83 & 0.99 & 0.79 \\
\hline 8 & Kaskad & 1.34 & 1.15 & 1.06 & 0.88 & $\mathbf{1 . 4 4}$ \\
\hline 9 & Zavet & 0.80 & 1.01 & 1.01 & 0.98 & 0.80 \\
\hline 10 & Skif & 1.06 & 1.25 & 1.14 & 0.84 & 1.27 \\
\hline 11 & Skolot & 0.81 & 1.07 & 1.11 & 1.08 & 1.04 \\
\hline 12 & Ramzay & 1.40 & 1.07 & 1.13 & 1.07 & 1.81 \\
\hline 13 & Proryv & 0.90 & 0.85 & 0.76 & 0.93 & 0.54 \\
\hline 14 & Barun & 0.69 & 0.84 & 0.80 & 1.01 & 0.47 \\
\hline
\end{tabular}




\begin{tabular}{|c|c|c|c|c|c|c|}
\hline 15 & Mudrets & 1.10 & 0.90 & 0.99 & 1.08 & 1.06 \\
\hline 16 & Makar & 0.80 & 0.84 & 1.02 & 1.18 & 0.80 \\
\hline 17 & Dozor & 0.55 & 0.80 & 0.88 & 1.05 & 0.40 \\
\hline 18 & Valentin-90 & 1.09 & 1.19 & 1.19 & 1.00 & 1.54 \\
\hline 19 & Knyaz & 1.21 & 0.95 & 1.04 & 1.12 & 1.34 \\
\hline 20 & Bordo & 1.14 & 0.84 & 1.15 & 1.08 & 1.19 \\
\hline 21 & Trizub & 1.24 & 0.85 & 0.90 & 1.07 & 1.02 \\
\hline 22 & Beta & 0.97 & 1.08 & 0.97 & 0.94 & 0.96 \\
\hline 23 & Popsuevskaya & 1.36 & 0.91 & 1.07 & 1.22 & 1.62 \\
\hline 24 & Gorchinske & 0.60 & 1.00 & 0.99 & 0.87 & 0.52 \\
\hline 25 & Interes & 1.26 & 1.14 & 1.10 & 0.93 & 1.47 \\
\hline 26 & Ayaks & 0.75 & 1.08 & 1.13 & 0.94 & 0.86 \\
\hline 27 & Pshenichne & 0.86 & 1.08 & 1.08 & 1.03 & 1.03 \\
\hline 28 & Svityaz & 1.04 & 0.87 & 1.00 & 1.07 & 0.97 \\
\hline 29 & Amulet & 0.88 & 1.05 & 0.88 & 0.89 & 0.72 \\
\hline 30 & Utro & 0.94 & 0.99 & 0.76 & 0.78 & 0.55 \\
\hline 31 & Mars & 0.88 & 1.19 & 1.28 & 0.95 & 1.27 \\
\hline 32 & Prometey & 1.39 & 1.16 & 1.16 & 0.99 & 1.85 \\
\hline 33 & Impuls & 0.92 & 0.96 & 0.90 & 0.86 & 0.68 \\
\hline 34 & Argento & 0.47 & 1.02 & 1.04 & 1.00 & 0.50 \\
\hline 35 & Aswo & 0.74 & 0.82 & 0.74 & 0.91 & 0.40 \\
\hline 36 & Disko & 0.92 & 1.13 & 1.15 & 0.97 & 1.16 \\
\hline 37 & Floiras & 0.83 & 0.89 & 0.85 & 0.96 & 0.60 \\
\hline 38 & Korvetta & 1.04 & 1.03 & 0.95 & 0.96 & 0.98 \\
\hline 39 & Prado & 0.80 & 1.01 & 0.93 & 0.9 & 0.68 \\
\hline 40 & Anvo & 1.30 & 1.14 & 1.09 & 1.04 & 1.68 \\
\hline 41 & Fidelio & 1.10 & 1.16 & 1.24 & 1.00 & 1.58 \\
\hline 42 & Chernobrivets & 1.33 & 0.72 & 0.93 & 1.15 & 1.04 \\
\hline 43 & Shalanda & 1.73 & 1.15 & 1.37 & 1.18 & 3.21 \\
\hline 44 & Buket & 1.68 & 0.89 & 0.94 & 1.18 & 1.66 \\
\hline 45 & Markiyan & 0.97 & 0.88 & 1.03 & 0.91 & 0.80 \\
\hline 46 & Sirs-57 & 1.29 & 0.99 & 0.89 & 0.95 & 1.07 \\
\hline 47 & Eldorado & 0.70 & 0.84 & 0.71 & 0.95 & 0.39 \\
\hline 48 & Witon & 0.86 & 0.98 & 1.00 & 0.98 & 0.83 \\
\hline 49 & Colina & 1.00 & 1.05 & 1.06 & 1.03 & 1.15 \\
\hline 50 & Monica & 0.88 & 0.96 & 0.68 & 0.84 & 0.48 \\
\hline 51 & Antey & 0.89 & 1.04 & 1.06 & 1.17 & 1.15 \\
\hline 52 & Patriot & 0.69 & 0.94 & 0.98 & 0.95 & 0.60 \\
\hline 53 & Tornado & 0.98 & 0.94 & 0.78 & 1.06 & 0.76 \\
\hline
\end{tabular}

Some researchers also used the indices of perspectivity, adaptive potential, Mexican, Finno-Scandinavian and the index of ecological plasticity in breeding practice on cereals $[11,12]$. Data characterizing the adaptive traits and ecological plasticity of winter triticale collection samples in the conditions of the Leningrad region were obtained, which are presented in Table 4.

Table 4. Adaptation traits and ecological plasticity of winter triticale collection variety samples in the conditions of the Leningrad region (average data for 2018-2020).

\begin{tabular}{|c|c|c|c|c|c|c|c|}
\hline \multirow{2}{*}{$\begin{array}{l}\text { No. } \\
\text { in VIR } \\
\text { catalogue }\end{array}$} & \multirow{2}{*}{ Sample } & \multirow[t]{2}{*}{ Origin } & Ip & $\mathrm{FSi}$ & $\mathrm{Mi}$ & Isp & $\mathrm{ds} / \mathrm{dk}$ \\
\hline & & & \multicolumn{5}{|c|}{ units } \\
\hline 3861 & Kornet - St. & Russia & 51.6 & 57.1 & 1.05 & 3.2 & 10.8 \\
\hline 3636 & Nemchinovsky -56 & Russia & 56.5 & 67.0 & 1.15 & 4.2 & 10.7 \\
\hline 3904 & Konsul & Russia & 54.2 & 70.0 & 0.88 & 4.1 & 9.6 \\
\hline 3908 & Almaz & Russia & 52.4 & 63.4 & 1.01 & 3.4 & 9.9 \\
\hline 3909 & Topaz & Russia & 58.1 & 66.3 & 0.99 & 4.1 & 9.8 \\
\hline 3839 & Bard & Russia & 48.6 & 65.0 & 0.64 & 3.3 & 10.5 \\
\hline
\end{tabular}




\begin{tabular}{|c|c|c|c|c|c|c|c|}
\hline 3637 & Don & Russia & 59.6 & 64.7 & 1.03 & 3.2 & 9.7 \\
\hline 3717 & Kaskad & Russia & 44.7 & 71.3 & 1.32 & 3.7 & 10.0 \\
\hline 4020 & Zavet & Russia & 68.4 & 79.6 & 0.79 & 4.4 & 7.2 \\
\hline 3931 & Skif & Russia & 57.1 & 98.7 & 1.04 & 4.9 & 6.7 \\
\hline 3932 & Skolot & Russia & 72.6 & 81.6 & 0.8 & 4.7 & 7.2 \\
\hline 4071 & Ramzay & Russia & 77.9 & 86.1 & 1.39 & 5.1 & 6.6 \\
\hline 3763 & Proryv & Russia & 65.3 & 66.6 & 0.88 & 3.3 & 8.2 \\
\hline 3760 & Barun & Russia & 51.7 & 52.1 & 0.67 & 2.8 & 9.6 \\
\hline 3762 & Mudrets & Russia & 60.9 & 60.2 & 1.09 & 3.7 & 8.3 \\
\hline 3914 & Makar & Russia & 79.6 & 64.1 & 0.78 & 4.3 & 8.5 \\
\hline 4021 & Dozor & Russia & 63.2 & 56.6 & 0.54 & 3.4 & 7.6 \\
\hline 4074 & Valentin-90 & Russia & 57.2 & 93.3 & 1.07 & 4.5 & 9.2 \\
\hline 4076 & Knyaz & Russia & 78.6 & 72.6 & 1.20 & 4.4 & 7.1 \\
\hline 4078 & Bordo & Russia & 67.0 & 74.1 & 1.12 & 4.5 & 8.2 \\
\hline 3969 & Trizub & Russia & 51.9 & 51.2 & 1.23 & 3.0 & 11.0 \\
\hline 3941 & Beta & Russia & 51.0 & 70.4 & 0.95 & 3.5 & 10.7 \\
\hline 3924 & Popsuevskaya & Ukraine & 54.5 & 51.6 & 1.34 & 3.4 & 10.4 \\
\hline 3970 & Gorchinske & Ukraine & 48.2 & 66.3 & 0.59 & 3.6 & 8.2 \\
\hline 3968 & Interes & Ukraine & 49.0 & 72.3 & 1.25 & 3.9 & 10.0 \\
\hline 3966 & Ayaks & Ukraine & 57.0 & 76.2 & 0.74 & 4.8 & 8.2 \\
\hline 3965 & Pshenichne & Ukraine & 69.2 & 80.7 & 0.85 & 4.5 & 7.0 \\
\hline 3963 & Svityaz & Ukraine & 53.7 & 52.6 & 1.03 & 3.45 & 9.9 \\
\hline 3956 & Amulet & Belarus & 47.9 & 68.3 & 0.87 & 3.19 & 10.4 \\
\hline 3926 & Utro & Belarus & 43.1 & 65.2 & 0.93 & 2.8 & 9.1 \\
\hline 3901 & Mars & Belarus & 46.7 & 71.9 & 0.87 & 4.3 & 10.4 \\
\hline 3900 & Prometey & Belarus & 48.5 & 69.8 & 1.37 & 3.9 & 12.8 \\
\hline 3899 & Impuls & Belarus & 46.0 & 61.9 & 0.91 & 3.2 & 9.6 \\
\hline 4000 & Argento & Poland & 50.2 & 62.8 & 0.46 & 3.6 & 10.8 \\
\hline 4001 & Aswo & Poland & 50.0 & 54.2 & 0.73 & 2.7 & 9.8 \\
\hline 4003 & Disko & Poland & 52.5 & 74.2 & 0.91 & 4.2 & 9.0 \\
\hline 4004 & Floiras & Poland & 58.0 & 62.4 & 0.82 & 3.3 & 10.5 \\
\hline 4005 & Korvetta & Poland & 65.5 & 78.8 & 1.03 & 3.7 & 7.5 \\
\hline 3865 & Prado & Poland & 48.4 & 65.3 & 0.79 & 3.3 & 10.4 \\
\hline 3999 & Anvo & Poland & 50.4 & 68.2 & 1.29 & 3.6 & 10.8 \\
\hline 3701 & Fidelio & Poland & 60.2 & 80.1 & 1.08 & 4.8 & 8.1 \\
\hline 4094 & Chernobrivets & Ukraine & 57.5 & 44.7 & 1.31 & 3.2 & 11.0 \\
\hline 4095 & Shalanda & Ukraine & 53.9 & 66.5 & 1.71 & 4.4 & 11.5 \\
\hline 4097 & Buket & Ukraine & 56.3 & 53.1 & 1.66 & 3.13 & 11.0 \\
\hline 4098 & Markiyan & Ukraine & 44.4 & 54.2 & 0.96 & 3.57 & 11.0 \\
\hline 4114 & Sirs-57 & Russia & 47.6 & 60.9 & 1.28 & 3 & 10.5 \\
\hline 3698 & Eldorado & Poland & 50.8 & 54.08 & 0.68 & 2.55 & 12.25 \\
\hline 3843 & Witon & Poland & 52 & 62.5 & 0.85 & 3.6 & 10.0 \\
\hline
\end{tabular}




\begin{tabular}{|c|l|c|c|c|c|c|c|}
\hline 3458 & Colina & Romania & 55.5 & 67.8 & 0.99 & 3.8 & 10.3 \\
\hline 3278 & Monica & Poland & 38.2 & 55.2 & 0.87 & 2.2 & 14.3 \\
\hline 3562 & Antey & Russia & 58.7 & 63.8 & 0.88 & 3.6 & 10.5 \\
\hline 3582 & Patriot & Russia & 64.6 & 69.8 & 0.67 & 4.1 & 7.0 \\
\hline 4142 & Tornado & Russia & 41.8 & 45.1 & 0.96 & 2.2 & 14.7 \\
\hline
\end{tabular}

The perspectivity Index (Ip) characterizes the ability of the stem to transform plastic substances directly into grain.

According to the Ip index, varieties Zavet (68.4), Skolot (72.6), Ramzay (77.9), Proryv (65.3), Makar (79.6), Knyaz (78.6), Dozor (63, 2), Bordo (67.0), Pshenichne (69.2), Korvetta (65.5) Patriot (64.6) were distinguished. Varieties Monica (38.2) and Tornado 5 (41.8) had low Jp.

The Finno-Scandinavian index (FSi) characterizes the grain-forming ability of an ear. Colina (67.8) was at the level of the high-yielding standard variety Kornet (67.0). Over $41.5 \%$ of the studied variety samples had an FSi index of more than 67 units, which corresponds to a good grain-forming ability of the variety. The highest values of the FSi index were observed in the following variety samples: Kaskad (71.3), Zavet (79.6), Skif (98.7), Skolot (81.6), Ramzay (86.1), Valentin-90 (93.3), Knyaz (72.6), Bordo (74.1), Interes (72.3), Ajax (76.2), Pshenichne (80.7), Mars (71.9), Disko (74.2), Korvetta (78.8), Fidelio (80.1).

The Mexican index (Mi) characterizes lodging resistance. In our studies, the selection threshold (over 4.2 units) for this indicator was exceeded by 15 out of 53 variety samples.

The adaptive potential of plants characterizes the resistance of varieties to lodging and is determined by the ratio of the stem length to the ear length (ds/dk). The best varieties according to this indicator were: Zavet, Skolot (7.2), Skif (6.7), Ramzay (6.6), Knyaz (7.1), Pshenichne and Patriot (7.0).

The ecological plasticity index (Isp) was used; it shows how much the studied variety sample has an advantage over other varieties [12]. According to this indicator, varieties are selected that will form a high yield in the region. In the studies, the best varieties in terms of Isp were: Kornet (1.15), Kaskad (1.32), Ramzay (1.39), Knyaz (1.2), Bordo (1.12), Trizub (1.23), Popsuevskaya (1.34), Interes (1.25), Prometey (1.37), Chernobrivets (1.31), Shalanda (1.71), Buket (1.66) and Sirs-57 $(1,28)$.

\section{Conclusions}

1. For the creation of new winter triticale genotypes with improved complex economically significant properties, increased resistance to bio- and abiostressors of the environment, the variety samples selected for all the studied indices are of interest - Ramzay, Knyaz, Bordo (Russia), Fidelio (Poland).

2. The index assessment made it possible to identify promising samples, which were also identified according to the data of statistical processing.

3. Analysis of the research results indicates the effectiveness of the indices method use in the comprehensive assessment of the genetic collection of winter hexaploid triticale.

The study was performed within the framework of the State Task according to the theme plans of: Leningrad Research Institute for Agriculture "Belogorka", branch of the A.G. Lorch Russian Potato Research Center, Project No. 0672-2019-0011 "Fundamental Principles of Breeding Process Management in the Development of Plant Genotypes with Economically Useful Traits of High Productivity, Resistance to Bio- and Abiostressors, and 
Obtaining New Knowledge on Agricultural Practices to Produce Original Seed Material by Modern Plant Diagnostics and Protection Methods that Secure the Yield of High-Quality Seeds in the Environments of the Russian Northwest"; and the N.I. Vavilov All-Russian Institute of Plant Genetic Resources (VIR), Project No. 0662-2019-0006 "Search for and Viability Maintenance, and Disclosing the Potential of Hereditary Variation in the Global Collection of Cereal and Groat Crops at VIR for the Development of an Optimized Genebank and Its Sustainable Utilization in Plant Breeding and Crop Production”.

\section{References}

1. N.S. Lavrentieva, L.I. Kuznetsova, T.T. Barsukova, M.A. Nutchina, L.P. Bekish, N.N. Chikida, Breadbaking of Russia, 4, 38 - 42 (2020) DOI: 10.37443 / 2073-3569-2020-14-38-42

2. K.G. Barylnik, L.I. Kuznetsova, N.S. Lavrentieva, N.N. Chikida, L.P. Bekish, N.M. Komarov, Proceedings on applied botany, genetics and breeding, 179 (1), 54-62 (2018) DOI: 10.30901 / 2227-8834-2018-1-54-62.

3. State Register of Breeding Achievements Permitted for Use, vol. 1 "Plant Varieties" (official publication), 719 (2021)

4. V.N. Gorbunov, V.E. Shevchenko, Achievements of science and technology in the AIC, 29 (4), 24-27 (2015)

5. L.P. Bekish, V.A. Uspenskaya, T.I. Peneva, N.N. Chikida, Proceedings on applied botany, genetics and breeding, 181 (4), 102-111 (2020) DOI: 10.30901 / 2227-88342020-4-9-18.

6. S.N. Ponomarev, M.L. Ponomareva, M.Sh. Tagirov, Zemledelie, 8, 34-38 (2018) DOI: 10.24411 / 0044-3913-2018-10810.

7. A.I. Grabovets, M.A. Fomenko, Legumes and cereals, 2 (6), 41-47 (2013)

8. V.A. Uspenskaya, L.P. Bekish, N.N. Chikida, Proceedings on Applied Botany, Genetics and Breeding, 179 (3), 85-94 (2018) DOI: 10.30901 / 2227-8834-2018-3-8594.

9. V.V. Voronchikhin, V.V. Pylnev, V.S. Rubets, Bulletin of the Kursk State Agricultural Academy, 7, 92-100 (2019)

10. L. Bondareva, D. Danilov, L. Kartashova, BIO Web of Conferences, 27, 00067 (2020) https://doi.org/10.1051/bioconf/20202700067

11. S.A. Eberhart, W.A. Russel, Crop Sci. 6(1), 36-40 (1966)

12. B.A. Field experiment method (with the basics of statistical processing of research results), 351 (1985)

13. Methodology for state variety testing of agricultural crops. Issue 1. General Part, 269 (1985)

14. Collection conservation, reproduction and study of wheat, triticale and aegilops: guidelines of VIR, 35 (1999)

15. International Comecon classifier of the Triticale genus, 26 (1984) 